\title{
AMERICAN GLADIATORS: KEEPING THE BODY IN SHAPE
}

Laura Baker

For the spellers, you've got Wheel of Fortune; for the guys who go shopping, you've got The Price is Right; for the athlete, you've got American Gladiators.

\section{Nitro}

Premiering in the fall of 1989 , the latest entry in a series of shortlived "crash television" shows that appeared in the late $80 \mathrm{~s}$, American Gladiators not only outlived its competition but has become the fifth most popular television show in syndication in the United States. Even the President watches it ("Channel 2 Sportscaster to Host "American Gladiators" 6). In addition to its success as a television showit is currently aired on over $97 \%$ of the U.S. market and in 50 foreign countries - it has also spawned a lucrative line of merchandise. Besides trading cards, action figures and video games, vitamins and food supplements, one can also buy more exotic products such as "American Gladiator" air fresheners and nougat candies.

A game show for the physically fit, hopeful contenders face off against muscular Gladiators in combat games inspired by action films. ${ }^{1}$ In what has proved to be a highly successful formula, American Gladiators combines the excitement of athletic competition with the glamour of Hollywood. The show's dual framing as competitive sport and spectacle of excess combines contradictory representations of the body: while the first functions to naturalize gender and racial differences, the second foregrounds their fabricated nature. What I want to examine here are the consequences these competing agendas have for the representation of gender and race on the show. I am particuarly interested in the way the show constructs feminity. While the images of physically powerful muscular women suggest alternative gender possibilities, they are embroiled in the imperatives of commercial fitness and health culture. The show's visual imagery, 
narrative overlay, and sport competitions combine to assert a hierarchy of bodies, stratified according to gender and race, that ultimately privileges the "managed" body of the fitness industry.

For a game show, the financial reward for competing on American Gladiators is nominal: contenders who appear on the show receive \$500; the male and female season champions $\$ 15,000$ each. What the show primarily offers is athletic glory. This, according to the Gladiator Gemini, is what attracts contenders: "We give the everyday blue collar worker who's kept himself or herself in shape a chance to show what he or she can do" (Simpson 102). ${ }^{2}$ The show's producers believe that its success on television is based on a similar appeal. By identifying with contenders' victories, television viewers can vicariously experience the power and thrill of defeating a Gladiator. They can, in Production Executive Julie Resh's words, "fantasize beating Nitro or Lazer in a way that's much closer to home than fantasizing they can be Joe Montana" ("Unlikely Heroes; Very Unlikely Hit" 6).

Resh's choice of examples is significant. As an athletic competition, the show functions as a masculine proving ground. "Who is the man," the Gladiator Turbo often asks rhetorically after beating a contender. Sports sociologists Laurel R. Davis and Linda C. Delano argue that "because of changes in the gender order due to the feminist movement, one of the few remaining ways for men to express and preserve traditional masculinity may be through the literal embodiment of characteristics that are perceived as masculine" (Davis 12). Sports, they contend, provide an ideal venue for men to both develop and display an embodied masculinity. For male contenders, facing off against a Gladiator offers an opportunity to test their masculinity against its ultimate embodiment in confrontational athletic games particularly suited to the expression of muscular masculinity. ${ }^{3}$ Those who defeat a Gladiator affirm not just their athletic ability but their manhood. This, according to Johnny Ferraro, the creator of American Gladiators, is what makes the show so popular: "It's been 2,000 years since the days of Rome. Now we have a different angle, a different look, but it's still man against man inside an arena" ("Unlikely Heroes; Very Unlikely Hit" 6).

Yet American Gladiators differs from conventional sports in that it embeds its athletic competition in circus-like spectacle and display. Male Gladiators wear flamboyant red, white and blue starstudded skin-tight lycra outfits. The theatricality of the games threatens to trivialize their athletic component. In Atlasphere contenders and Gladiators battle each other as they roll around in spherical metal cages. In Joust, they beat at each other from atop platforms with giant Q-tip-like pugilist sticks. In Sky Track, suspended upside-down in harnesses, they propel themselves along an aerial racetrack with 
Velcro gloves and shoes. Furthermore, the "hard" bodies of the Gladiators perform in the incongruous "padded" environment of the Gladiator Arena. Elaborate safety gear, thick foam mats, and spotters armed with pillow size cushions suggest that the games are more stylized display than real competition.

If the male Gladiators' masculine posturing is an assertion that they are the men, it is also a part of the show's strategy to heighten the dramatic tension of the "David and Goliath"-like confrontations between Gladiators and contenders. ${ }^{4}$ Profiles of the male Gladiators feature them boasting of or performing exaggerated displays of muscular masculinity. One of the more humorous ones, a dramatized illustration of Tower's name, features him "towering" over miniature highrise office buildings. "I am the tower. I have the power," he voices over as he walks among them. As the camera cuts to him crushing a matchbox car underneath the heel of his hightop, in a deep, solemn tone he continues, "Some people say that bigger isn't better. I agree, it isn't better, it's the best."

In general, the male Gladiators' masculine displays verge less precariously on parody. One of the show's visual conventions features brief shots of the competing Gladiators as they prepare to take on a contender. The men often use this shot to throw a bodybuilding pose, usually flexing a bicep as they glare into the camera. Gladiator trading cards, wall calendars and profiles of the male Gladiators in the American Gladiators Magazine also feature images of the men displaying their muscular bodies in standard bodybuilder poses. While these images offer visual evidence of the male Gladiators' muscular masculinity, they also embroil the men in "feminine" display and exhibitionism. As sports sociologist Alan M. Klein argues, bodybuilding as masculine display is plagued by "feminine" aspects of the sport-the narcissism suggested by the inordinate amount of attention bodybuilders pay to their bodies and the vanity suggested in their bodily display. Furthermore, the male Gladiators, and the camera's, emphasis (enhanced by their minimal, skin-tight outfits) on the shape and contours of their bodies imbue their muscular displays with erotic possibilities-positioning them as objects of desire and implicating male heterosexual viewers in homoerotic desire.

The show's participants and the promotional discourse surrounding it are noticeably quiet about the show (and the male Gladiators) as spectacle. Instead they emphasize the athletic authenticity and seriousness of the games. In mini-interviews with the contenders after each event, commentator Lisa Malosky encourages them to tell viewers at home "just how tough it is." In one of the few articles on the show that appears in the sports media, Tracy Jernegan describes how he "was always opposed to watching [the show]. It looked phony to me. Then I realized it was the real thing. After I sat down and really 
watched it, I could see they weren't kidding around" ("On Fire in the Arena" 6)..$^{5}$ Coverage of the show in American Gladiators Magazine points to the number of injuries sustained by Gladiators and contenders alike as proof of the games' seriousness. The show's format also encourages viewers to read the show as sport. Two commentators, Mike Adamle, an ex-football announcer for NBC, and Malosky, call the "play by play" action. Events are timed with an "official" Armitron stopwatch displayed on the television screen. This past season, in an attempt to incorporate a more upscale look, the show has added sports magazine style features, such as locker room interviews with the Gladiators and taped profiles of the contenders. Yet, despite the emphasis on authenticity, the male Gladiators' and contenders' performances rest precipitously between athletic display and theatrical and erotic spectacle, the possibility of the latter two threatening to undermine the (heterosexual) masculinity proved by the former.

Women's participation on the show also threatens to disrupt its use of sport as masculine expression. Considering that the show was originally conceived for an audience of adolescent and adult males, Samuel Goldwyn Television's inclusion of women was likely motivated by their physical marketability. ${ }^{6}$ The women Gladiators also wear red, white and blue lycra outfits, although their's are cut high across their thighs and low across their cleavage in a style reminiscent of Linda Carter's Wonder Woman outfit. While their sexualized representation may profit the American Gladiator franchise, their inclusion on the show is not without its benefits to women athletes. Being a Gladiator is one of the few professional opportunities available to women bodybuilders. Aside from professional golf and tennis, the show offers the only regularly televised opportunity to view female athletic competition. It is the only televised show that features women competing in contact sports, where their direct exertion of power, albeit over another woman, challenges notions of feminine passivity and powerlessness. ${ }^{7}$

The show's competing sports and entertainment agendas create a situation ripe with gender confusion. Men, despite their display of strength and aggressiveness, are embroiled in "feminine" display. Women, despite their sexualization, are also part of the show's competitive athleticism. The latter in particular jeopardizes a gender system that depends on unambiguous, "natural" physical differences between the sexes. If the blurring of gender boundaries/bodies threatens male dominance, it also threatens to undermine "normal" (hetero)sexuality. The muscular female, whose own sexuality is put in question by her "butch" appearance, possesses the power not only to challenge male dominance but, as film scholar Lourie Jane Schulze argues, to invert "normal" male sexuality. This danger "lurks in the implication that any male sexual interest in the muscular female is not 
heterosexual at all, but homosexual" (Schulze 43). The containment of any implication of homosexual desire becomes even more urgent in the homosocial worlds created by the show's rigid separation of men's and women's competitions-a separation that serves, ironically, as one of its means of reaffirming gender boundaries.

The show's visual imagery, narrative overlay, and selection of contenders whose appearance and behavior conform to normative gender expectations suggest an abiding anxiety over the gender and sexual boundaries that it blurs. The commentators' narration consistently differentiates the female from the male contenders, in particular by feminizing the women. ${ }^{8}$ Jennifer Tantum, a striptease dancer, is introduced as "curvy Jennifer." Kimberly Tyler's femininity and beauty is commented on repeatedly. April Wheat, a cheerleader who evinces considerable energy and endurance, is referred to as "tiny," "diminutive" and "the human pep pill." (A similar emphasis on men's appearance is noticeably absent.) Lisa Malosky, interviewing Elizabeth Albright at the "start line" of the Eliminator, the show's final event, notes that she's been "huddling" with her husband between events getting advice-and what did he have to say before the Eliminator? ${ }^{9}$ Mike Adamle, commenting on firefighter Cathy Marino's perseverance, identifies her not by her occupation, the commentators' conventional way of identifying contenders, but as a mother: "What will a thirty-five year old woman and mother of a three year-old son has!" By highlighting the female contenders' femininity, and in Marino's case age, these comments work additionally to the show's advantage (as spectacle) by making women's strength and athleticism all the more amazing-coming, as it does, from such "feminine" women. They also work to contain the women's athletic achievements by implying the incongruity of femininity and strength.

More than the female contenders, the Gladiator women threaten to erode gender boundaries. Not only is there little difference between their athletic ability and strength and that of most of the male contenders, but their visible muscularity undermines the show's investment in an embodied masculinity. As Zap notes, her "arms are bigger than those of some of the guys on the show" ("Real Life Davids vs. Goliaths" 130). It is in the contradictory representation of the women Gladiators that the tension created by the show's competing agendas becomes most apparent. On the one hand, as part of the show's "David meets Goliath" formula of competition, they are narrativized as powerful, menacing athletes. The women themselves take the competitions very seriously and, particularly Ice and Zap, enjoy drawing attention to their muscular physiques. Ice tests gender boundaries even further by mimicking the men's aggressive posturing. "Do you know what our motto is?" she asks a nervous Renee Lockey preparing 
to run the "Gauntlet" against Ice and three other Gladiator women. "Eat "em up and spit "em out."10

On the other hand, the visual representation of the women Gladiators as athletes is much more ambivalent. Instead, they are imaged in ways that encourage an unambiguous reading of them as "feminine." One of the show's signature shots is a low angle medium close-up of the Gladiators - they appear to be almost standing over the camera. For the men, who usually glare into the camera, flex their bicep or roar a challenge, the shot exaggerates their size and height. While women may pose or perform in a similar fashion (though more often they are shown standing still or posed staticly), the angle of the camera has the effect of exaggerating the size of their breasts. Looming unnaturally large, they become the central focal point of the image. Not surprisingly this shot is used most often with Zap and Ice, the most buxom of the Gladiators.

Less distinctive shots also work to feminize the female Gladiators. In an opening sequence following a commercial break the camera zooms up and in on Electra, who stands with her back to it on the Assault tower. ${ }^{11}$ The graphic announcing the game's name blocks her torso from view. Only her legs, elongated by the camera angle, and her head are visible. The first three letters of "Assault" literally cover her own. As the camera continues to zoom in on her, the graphic breaks up and disappears from the screen to reveal "the real thing." The shot of her preceding the start of the game continues to emphasize her feminine features. The tightly framed shot of her face in profile highlights her long hair, plucked eyebrows and lipsticked lips. In contrast, the same "pre-game" shot of the male Gladiator Laser is a long shot from the back of the platform. Laser, throwing a doublebicep pose, occupies the left third of the image. The "gun" he is about to use is centered in the frame. Behind him the entire playing field is visible, giving a sense of Laser's vaulted position. (After the event is over, Laser tells Malosky, "I love the gun.")

As the aggrandized framing of Laser suggests, male Gladiators and contenders are represented quite differently than the women, both visually, as in the examples described above, and discursively. The commentators' coverage of events emphasize men's display of strength and courage. In covering the "Pyramid," where Adamle describes the women as "scrambling," and falling "topsy turvy" down to the bottom, he describes the men as "battling" it out and taking each other "down hard." Following one event, we find out that the Gladiator Tower competed with a dislocated wrist. He reassures the viewer that he "feels no pain. It's time to turn it up one more notch. Forget about it."

Such Rambo-like manliness (to whom journalists often compare the Gladiator men) is equally emphasized in the mini-interviews that frame each event. In one show the Gladiator Saber "usurps" the 
interview and commands the camera to follow him. It does-into the back stage Gladiator gym. "I just beat two grown men in Conquer back to back," he reminds his viewers. "Let's just go see what I can do while I'm sweating." He proceeds to benchpress 405 pounds five times. In another interview, the male Gladiators' strength is presented explicitly as the basis of patriarchal authority and masculinity:
Adamle: "I know you guys like to have fun talking about Gladiator Arena as your house, your turf. But you looked at those two contenders as if they were trespassers, Tower." Tower: "That's right, they're in my house. And you know what I do to trespassers, Mike. I hit 'em hard, and I hit 'em tough."
Adamle: "The intensity level-its obvious you've turned it up several notches, Turbo."
Turbo: "We've got some incredible contestants here. And I've just got to ask you one question, Mike, who is the man?" Adamle: "You both were the men that time."

There is a kinder, gentler, distinctly heterosexual side to the men's masculinity. Shots of contender's wives and girlfriends applauding their partners victories are regularly featured (the more conventionally attractive the women, the more often). "Nobody loved Mark Muse's performance more," Adamle comments enthusiastically after Muse defeats a Gladiator, "than Mark's wife Tracy." Contenders' fatherhood is also emphasized. A profile of Lanny Ross, "a single father of three," shows him shooting basketball hoops with "his little son, five-year-old Danny." A profile of Sean Goodwin, also a single father, features him rock climbing with his five-year-old son Charlie while Adamle narrates: "They are inseparable. Usually where Dad goes, Charlie's right behind. Always together. Like father, like son." From "30 Seconds with Laser", a short question and answer "interview" aired for each of the Gladiators, the viewer learns that, when he's not training to be a Gladiator, he "loves being a Daddy." These representations of the men as fathers likely facilitate boys' viewing identification. They also idealize a homosocial world. Susan Jeffords argues in The Remasculinization of America that the emphasis on fatherhood in films of the past decade reflects a renewed cultural interest in patriarchal figures as sources of security and guidance. With Ross and Goodwin, not only are they represented as sources of guidance for their sons, it is made clear that they are the only source. Mothers (and daughters) become superfluous in their self-sustaining masculine world.

By making the female participants legible as women, and the male participants legible as men, the show's narrative and visual representational strategies both reproduce them as different and ease 
anxiety over the possibility that they are not. The show's competition format also works to construct them as different. Sports sociologist Susan Birrell argues that sport produces a "logic of differentiation." That is, "the point of sport is to display publicly the processes of challenge and struggle between two sides alleged to begin on equal terms but determined to produce and sustain relations of dominance vis-a-vis one another." Moreover, she notes, the view of sport as a meritocracy based on achievement not only "quietly" reaffirms our national commonsense that hard work will always pay off; it implies that those who reach the top deserve to be there, and those who do not simply lack the "requisite talent for such privilege. Even the runnerup is a loser" (Birrell 213).

The show's elaborate format creates multiple competitions that not only differentiate the men from the women, but the (racially distinguished) superior athlete from the inferior, and the Gladiators from the contenders. Two female contenders and two male contenders compete in a show. In each of the four or five events in which they compete against the Gladiators they have the opportunity to earn up to 10 points. Their cumulative scores merely determine their position in the final event, the "Eliminator," a timed obstacle course. The difference between the two contenders' scores is divided in half and the person who had more points is than given that many seconds head start. It is the winner of the Eliminator that continues on to the next round. While male and female contenders never compete directly against each other, their competitions are played, timed and scored in the same way, making them easily comparable. Though Gladiators are not scored, their performances are also comparable-a fact the women Gladiators appear to be quite conscious of. After swiftly beating a contender in Joust, Zap tells Adamle, "I see the guys knocking them off in two hits. I say, 'three hits' - boom, boom, boom, and gone!" As Zap's comment suggests, the men, Gladiators and contenders, generally perform better than the women, appearing quantitatively superior to the women athletes.

The show's competition format also works to racially differentiate the participants. While the show only indirectly compares men's and women's athletic ability, Blacks and whites often compete directly against each other. ${ }^{12}$ Two of the male Gladiators this season, Saber and Rebel, are Black. Jazz is the only female Black Gladiator. However, almost half of the contenders are Black, making almost half of the match-ups between the men and almost two-thirds of the matchups between the women interracial. ${ }^{13}$ Occurring most often, though, are interracial match-ups in contender-Gladiator competitions. Even if a Black contender beats a white contender in the Eliminator and wins the show, he or she has likely lost to one or more of the white Gladiators, effectively containing the possibility of uncontested Black 
athletic, and, for the men, masculine superiority. Here, the male Gladiators' boast "I am the man," spoken only by the white Gladiators, takes on an additional meaning in the show's racialized competitions; it becomes an assertion of white male authority.

The show's own construction of race is ambivalent. Insofar as it privileges gender as the transcendent category of difference, it serves dominant race interests by diffusing racial tension and difference. Yet the discursive representation of the Black Gladiators wavers between emphasizing their assimilation into the Gladiator "team" and exploiting racial stereotypes that imbue them with a menacing power. Interviewing the rookie Rebel, after he successfully defeated both contenders in Tug-o-War, Adamle asks him directively: "I know the biggest thing you're worried about is proving yourselfnot to yourself but to your Gladiator teammates." In contrast, during events, the commentators play up Rebels size. Adamle repeatedly describes him as "our biggest Gladiator" or as " 285 pounds of Rebel."

In her "30 Second" profile, Jazz, a rookie, when asked what her goal as a new Gladiator is, answers "to fit in and succeed." Yet a number of other questions emphasize and exoticize her racial difference. She is asked from whom she got her "thoroughbred physique." Another question reveals that, if she were an animal, she'd be "a jaguar." The contenders and commentators also animalize Jazz. After losing to Jazz in Whiplash, Jennifer Tantum, a white contender, tells Malosky: "It's horrible. It's like trying to pull a horse out of a ring or something. She is strong!" Adamle comments: "Well, Jennifer, I'm sure Jazz would prefer foxy, filly, or thoroughbred to horse but you do have one thing right, she is powerful." The animalization of Jazz suggests a racially differentiated construction of femininity. Aside from her association with the exotic image of a jaguar, she is noticeably absent from the discursive and visual sexualization of the Gladiator women. If this counters the racist view that Black women are intrinsically sexual, it also implies that she is an inappropriate object of desire.

Saber, a veteran of the show, is the most racialized Black Gladiator. Similar to Jazz's, his representation also suggests a racially differentiated construction of masculinity. In his profile, the most elaborate of the first half of the season, he is featured performing a rap song:

Everybody, everybody say they wanna go

be on the Gladiator show.

Well you know

that if you finally make it to T.V.

you're got to see me:

S-A-B-E-R Saber. 
Saber, Saber like the blade.

Knocking people down is how I get paid.

The visual images of the sequence alternate between a shot of him in the Gladiator studio, in the back seat of a convertible wearing dark sunglasses, dressed not in his singlet but in a "gansta" suit, and in front of wrought iron gates that blocks what appears to be the driveway of a mansion. The threat of his criminalized image is partially subverted in this last shot. His weapon is not the "blade" he compares himself to in the song, but merely a fencing foil. This shot is shown twice. The second time, he is behind the bars, through which he impotently thrusts the foil. Saber is simultaneously criminalized and incarcerated, sexualized and emasculated. Still, the image promotes the fantasy that if a contender beats Saber, he has overcome not only a Gladiator, but the threat of Black male criminality and sexuality that Saber personifies.

The show as sport competition has profound implications for the way it produces and reproduces gender and race. Given that sport is thought to "derive its essence from its physical nature," a meritocratic view of sport reproduces these categories as natural and biological (Birell 223). Media coverage of the show further naturalizes the gendered and racialized body. Although the excessive bodybuilding physiques of the Gladiators and many of the contenders suggest the malleability of the body, it stresses that these bodies are managed, not produced-"kept in shape," as Gemini puts it in the statement quoted at the beginning the essay. Any implication of steroid use, which would also point to the body as produced, is noticeably absent in this discourse. Instead, the "purity" of the Gladiators' bodies is emphasized. Stella, the mother of two boys, tells a journalist that she believes the Gladiators are good role models for her sons because "they don't do drugs, they eat the right foods, they take pride in their bodies" (Simpson 102). When a journalist asks Zap what she thinks of steroid use, she answers that she's glad the bodybuilding industry is "finally doing something about it. It was really evident with women body builders. They make women very masculine and that is not a good point in my book. No one should take anything to enhance their natural abilities" ("Talking With American Gladiators" 2). ${ }^{14}$ No one should take drugs to enhance their "natural" abilities, but to be a contender, leastwise a Gladiator, one must have developed them to their fullest potential. As Zap puts it, the Gladiators "should be seen as America's most elite bodies" ("Real Life Davids vs. Goliaths" 130).

The show's self-stylization as an athletic game show for the blue collar worker-Johnny Ferraro calls it "the hard hat Olympics"raises important questions about how, exactly, the participants' bod- 
ies are developed. The show purports to celebrate the rough-hewn, muscle-bound working-class body of Labor. According to one of its "origin myths," the idea for American Gladiators was born decades ago in the mind of Johnny Ferraro, who was inspired by the hand to hand competition he witnessed between steelworkers at a company picnic in Erie, Pennsylvania ("Unlikely Heroes; Very Unlikely Hit" 6). In another, most likely more accurate version, Dan Car, five time national arm wrestling champ, wanted a "working man's Olympics." He created the contests in 1971 as entertainment for the annual Erie Iron Workers Union picnic. In 1983 he asked Ferraro for help to turn the event into a charity benefit. When 3000 people showed up, Ferraro realized the mass appeal potential of the contests and was ultimately able to sell the idea to Samuel Goldwyn Television (Simpson 102).

However, only a small percentage of the show's contenders are blue collar workers. The majority are white collar workers, professionals, and college students. ${ }^{15}$ All of the current Gladiators' have previous job experience as professional athletes, bodybuilders or white collar workers. That male contenders occasionally attribute their athletic success to their profession suggests that the story of the show's working class origins enhances the show's appeal by associating white collar workers with a mythology of brawny, muscular, working-class masculinity. ${ }^{16}$ Interviewing state trooper Mark Muse at the "finish line" after he wins the semi-finals, Malosky congratulates him saying "I know there are a lot of state troopers all across America who are beaming because you just did them proud." A solemn Muse responds, "Most definitely. New Jersey state police are number one and I just proved it."

Despite its self-presentation as a working-class Olympics, with few exceptions, the bodies of the show's participants are developed in gyms and fitness centers, not on the job through their paid labor. ${ }^{17}$ As Casey Lanken, an American Gladiators sales representative describes it, "It's a fitness thing ... something to do after you work out in the gym" ("The American Gladiators Take on Chicago" 67). Ironically, the only self-identified blue-collar contender, Andy Kamp, a greenhouse laborer, is represented as athletically inferior. Midway through the show, Adamle points out: "Well, one of the things Andy promised was to give the audience a good show. He's done that, but he's yet to score any points." Neither does Kamp reflect the disciplined manhood the show promotes. ${ }^{18}$ At the start line of the Eliminator, Malosky asks, "Andy Kamp, you say you represent blue collar workers of America. Andy, what have you got to say to those guys before this competition begins?" He responds enthusiastically, "Hey guys, this one's on me. Kick off your boots, take off your blue collars. Let's kick back and watch me go. Scream!" After he loses to the other contender, Adamle comments, "Well, Andy Kamp certainly has what 
it takes. He may not possess the most athletic talent in the world, but he knows that heart, spirit and determination can make up for physical shortcomings." 19

Adamle's emphasis on Kamp's attitude and pride reflects the primary way the show effaces contenders' defeat. When it becomes clear that April Wheat cannot hold her own against the Gladiator women, Adamle comments that "the diminutive cheerleader from Texas probably won't win this thing, but she'll compete as she always does, with a smile on her face and a whole lot of heart." Despite Samuel Goldwyn's claim that "[m]any of the contests require brain over brawn, so that the little guy has a chance," the "little guy" rarely wins ("Unlikely Heroes; Very Unlikely Hit" 6). Instead, it is usually only the contender whose muscular development and weight approaches the Gladiators that is able to defeat them. This is particularly true of the six one-on-one events, in which a number of the Gladiators are undefeated. ${ }^{20}$ The body that dominates these contests, that emerges as superior, is the highly manipulated, developed body of the Gladiators.

By privileging the Gladiator body, the show promotes an ideal of body management and self-discipline. As a letter from an aspiring Gladiator indicates, achieving this ideal requires commitment to a strict diet and exercise regime: "I work out five times a week, two hours a day, I never miss a meal, and I always make sure I eat healthy foods. I never drink or smoke" (American Gladiator Magazine 5). More importantly, this fan's regime suggests how this ideal, through its synthesis of leisure, consumption and work, renders (and requires its subject to be) not only an athlete but a consumer and worker as well. On the one hand, the ideal of body management connects leisure and consumption (of fitness clubs, gyms, workout attire, health food); on the other, the ideal of self-discipline connects leisure and work (in the ways that an exercise regime and the fitness technology it utilizes extend the workday regimentation of the body). Not one to lose out on a merchandising opportunity, the Gladiator franchise itself is cashing in on the "managed" body it promotes. One can purchase (if she catches the half-hour infomercial through which they are sold) Body Plus exercise machines that feature the "American Gladiators" name and logo.

The show's promotion of such self-conscious body management has important implications for the way it constructs femininity. While the image of physically empowered, muscular women threatens to disrupt gender dichotomies, the show, and the female participants themselves, hardly reject femininity as an identity. Siren's declaration, after beating a contender in Conquer, that "Gladiator women are strong and beautiful" may challenge specific configurations of femininity but it does not challenge the category itself. The conservative 
preservation of femininity is even more striking in Zap's self-presentation. A profile of Zap features her jogging along the beach-in slow motion-in a bright pink bikini as she voices over: "I think you can be strong and sexy." She is currently trying to reduce muscle in preparation for an acting role in an action film, The Final Risk. "I think it looks better on screen when I'm lighter," she explains. I don't like being as bulky. I don't think it's as feminine" (American Gladiator Magazine 56). Perhaps not coincidentally, Zap is the only female Gladiator who remains from the show's original line-up.

Siren's and Zap's comments suggest that the show's female participants have invested in a new feminine aesthetic, one that is athletic, toned, lean and "healthy" - and only achieved through vigorous body management. A profile of Ice in American Gladiators Magazine reveals that she "[w]orks out five days a week and says she lifts for tone, not for size... Likes to keep her diet clean, meaning no fats, sugars, or salts, and plenty of chicken, rice, potatoes, and vegetables." In response to a letter from a female fan asking what her training routine and diet is, Siren writes: "I'll do about an hour-anda-half or more in the morning of intense heavy weight training. Then I'll follow it up with two or three types of aerobics..." Her husband adds, "Her diet is extremely monitored, which is something I do. She eats four or five meals a day, and right now she's at about 2,200 calories daily. It's about 40 percent protein, 50 percent carbohydrates, and 10 percent fat" (American Gladiator Magazine 21, 57).

Elizabeth Kagan and Margaret Morse have argued that this new, highly rationalized feminine aesthetic reflects the synthesis of beauty and fitness culture. Through aerobics and, I would add, weight training, "rather than masking the devalued, aging body one was given by nature, a woman can take the initiative and sculpt her own body toward a new ideal of slender but powerful and curvaceous femininity" (Kagen 166). It is a femininity that offers economic payoffs: "Because demands on and expectations of women have become so out of line with real possibilities, women are more dependent than ever on their bodies as a means of exchange with the world. When all else fails, attractiveness and youth are a kind of cultural capital" (Kagen 176). It is, literally, for contender Jennifer Tantum, the strip tease dancer, and for all of the Gladiator women. It also offers emotional payoffs. When asked in an interview how her family feels about her being a Gladiator, Zap replies: "Well, my sister, who is 30 , was always overweight. Since I became a Gladiator she has lost 60 pounds and now she is very thin and sure of herself" ("Talking With American Gladiators" 2).

Even as American Gladiators blurs gender boundaries, it simultaneously reasserts a femininity marked by self-discipline. Women's search for self-esteem and empowerment through exercise and sports 
is not a misguided effort. However, the managed feminine body promoted by the show contains women's athleticism within a conservative gender regime in which they are both consumers and consumed.

More generally, the show's idealization of body management has important implications for its alleged democratic accessibility and meritocratic nature, as well as for its self-presentation as a showcase for working class athletic talent. In order to compete on the show, let alone be a Gladiator, one has to have the leisure time and financial resources to create and maintain a competitive body. It is not surprising, then, that the majority of the show's participants work in white collar, middle-class occupations. Perhaps Zap's assessment comes closest to describing American Gladiators-it is a showcase for "America's most elite bodies." But the caveat would need to be added that some bodies are more "elite" than others.

\section{Notes}

${ }^{1}$ According to Kevin Fox, the show's tryouts coordinator, the games "are based on adventure movies. Storming machine gun nests. Standing on a log, trying to knock somebody off. Climbing a mountain, avoiding people chasing you" ("The American Gladiators Take on Chicago" 67).

${ }^{2}$ Despite the gender equity implied by Gemini's non-sexist language, observers have noted that the overwhelming majority of contenders hopefuls who tryout for the show are male. See David Leslie, "American Gladiators: Beyond the Thunderdome" (Leslie 56, and Dinero).

${ }^{3}$ Laser, at 5' 11 " the smallest of this season's Gladiators, weighs 222 pounds and bench presses twice that. Almost all of the games feature one on one competition with a Gladiator. Eight of the show's thirteen games require directly overpowering the Gladiator to win.

${ }^{4}$ The show's commentators, promotional material, and media coverage all use this "David and Goliath" metaphor to describe the competitions. A professional tennis player who tried out for the show believes the screening process is slanted toward all around athletes who tend to look small next to the body builders who they've hired as Gladiators (Waddington, 1C).

${ }^{5}$ American Gladiators receives press primarily in the entertainment and business sections of newspapers and periodicals. Only occasionally are articles on the show published in sports section. While Los Angeles Times staff writer Jeff Meyers treats the show as a genuine athletic competition whose status is hampered in the sports industry by its television format, he is in the minority (Meyers 17). In general, the show is not recognized by sports media as legitimate, a dismissal that further destabilizes the masculinity of its participants.

${ }^{6}$ Commercials aired during the show still assume a male audience. The lead off commercial of almost every commercial break is for a video game. At least once 
during the show a commercial for the Army or Navy is aired.

${ }^{7}$ This season, perhaps in recognition of and response to what it perceives to be a growing female audience, the show replaced one of its two male commentators with Malosky.

${ }^{8}$ The analysis that follows is based on the ten shows of the first half of the 1993-94 season. Eight female and eight male contenders competed in a series of elimination rounds to determine the "first half champions."

${ }^{9}$ Not only does Malosky's observation ease anxiety over Albright's independent, athletic image by drawing attention to her dependence on a man is also confirms Albright's heterosexuality.

${ }^{10}$ While Ice's "masculine" performance can be read as parodic, it is, as are the other Gladiator women's performances, easily reabsorbed within the framework of "amazonian" images that permeate mass media representations of strong, "masculine" women. In fact, a number of journalists who write about the show identify them as such.

${ }^{11}$ In Assault, a Gladiator fires tennis balls at a contender from a high platform. The contender has four opportunities to hit a target above the Gladiator with their own assortment of weapons. The Gladiator wins by hitting the contender, the contender by hitting the target.

${ }^{12}$ Race, on the show, is literally reduced to Black and white-encouraging the view that race in America is simply an issue of white and "other."

${ }^{13}$ Of the eight men competing in the first half of the season, four are Black; of the eight women, three.

${ }^{14}$ On the show, the commentators also naturalize the Gladiators' bodies. Adamle regularly points out how the Gladiators begin Tug-o-War at a technical disadvantage (they are tipped forward on the cantalevered platforms) because of their "natural strength and size advantage."

${ }^{15}$ This observation is based on the occupations of the 16 contenders competing in the first half of this season, as well as on descriptions of past contenders' occupations obtained from press coverage of the show. The first half of this season featured two firefighters, one state policeman, three salesmen, an Army administrative specialist, an aerospace physiologist, and industrial relations specialist, three students, a karate instructor, a strip tease dancer, a cabinet maker and a greenhouse laborer.

${ }^{16}$ The story of its working-class origins may also create an additional tension insofar as the Gladiator women's blurring of gender boundaries threaten, in the context of the show as a working class Olympics, male dominance in the work force. Here are women who clearly could do a "man's" job.

${ }^{17}$ Ferrara compares the Gladiators to both Rambo and Batman ("Unlikely Heroes; 
Very Unlikely Hit" 6). It would seem that Batman, who is financially and technologically enabled, is ultimately the more fitting comparison.

${ }^{18}$ Nor the gutsy, fearless manhood the show promotes. When Malosky asks him if Laser gave him a workout in Hang Tough, Kamp responds: "Well, it's called running for your life. I think you know what I mean-if you've ever been in a situation like that, you book, and you find some juice!"

${ }^{19} \mathrm{Kamp}$ is represented unfavorably visually as well. Contenders are identified throughout show with small ID portrait style photos-basically mugshots. There is a distinct contrast between James Franshier's, the other male contender, and Kamp's photos. James is pictured in a dress shirt and tie. His hair is cut short neatly combed. Kamp, on the other hand, is pictured in a t-shirt. His hair is long and disheveled. He looks like his idol, Ted Nugent.

${ }^{20} \mathrm{It}$ is in the other seven events that contenders most often score. Comparable weight and strength are not as important in Skytrack, a race game, the Wall, in which contenders are chased by the Gladiators up an artificial face, and Assault. Powerball, Atlasphere and Swingshot are contact games that, save for Powerball, are technologically mediated. Contenders are usually able to score some points in these. The Gauntlet can be won by evading the Gladiators, but more easily by powering through. However, because of the way the competition is structured, the show can afford to have the Gladiators almost always win without affecting the outcome of the competition; neither contender could beat a Gladiator and one would still emerge the "winner" of the Eliminator.

\section{Works Cited}

American Gladiators Magazine, Winter 1993.

“The American Gladiators Take on Chicago." Chicago Tribune, 19 March 1992.

Birrell, Susan. "Racial Relations Theories and Sport: Suggestions for a More Critical Analysis." Sociology of Sport Journal 6 (1988): 212-227.

Davis, Laurel R. and Linda C. Delano. "Fixing the Boundaries of Physical Gender: Side Effects of Anti-Drug Campaigns in Athletics." Sociology of Sport Journal 9 (1992): 1-19.

Dinero, G. Who's Hot: American Gladiators. New York: Dell Publishing, 1993.

Hodges, Ann. "Channel 2 Sportscaster to host 'American Gladiators."' The Houston Chronicle, 13 April 1993.

Jeffords, Susan. The Remasculinization of America. Bloomington: Indiana University Press, 1989.

Kagan, Elizabeth and Margaret Morse. "The Body Electronic: Aerobic Exercise on Video: Women's Search for Empowerment and Self-Transformation." The 
Drama Review 32 (1988): $164-80$

Klein, Alan M. "Pumping Irony: Crisis and Contradiction in Bodybuilding." Sociology of Sport Journal 3 (1986): 112-133.

Leslie, David. "American Gladiators: Beyond the Thunderdome." Village Voice, 12 June 1990.

Meyers, Jeff. "These Gladiators Perform in a Tubed Shaped Arena." Los Angeles Times, 7 September 1990.

“On Fire in the Arena." Los Angeles Times, 25 June 1992.

“Real Life Davids vs. Goliaths.” Time, 14 May 1990.

Schulze, Lourie Jane. "Getting Physical: Text/Context/Reading and the Made-forT.V. Movie.” Cinema Journal 25.2 (1986): 38-59.

Simpson, Janice. “Real Life Davids vs. Goliaths.” Time, 21 October 1991.

“Talking With American Gladiators.” Newsday, 3 November 1991.

“Unlikely Heroes; Very Unlikely Hit.” Los Angeles Times, 8 September 1991.

Waddington, Chris. “American Gladiators; Local Athletes Play David to TV Goliaths.” The Star Tribune, 8 November 1991. 